\title{
Integrasi Pendidikan Mitigasi Bencana Berbasis Kearifan Lokal Suku Sasak dalam Teks Prosedur pada Pembelajaran Bahasa Indonesia kelas XI SMA
}

\author{
Bukhori Muslim ${ }^{1}$; Sukran Makmun ${ }^{2}$ \\ ${ }^{1}$ Universitas Nahdlatul Wathan Mataram: bukhorimuslim@unwmataram.ac.id \\ ${ }^{2}$ Universitas Nahdlatul Wathan Mataram: sukranmakmun@gmail.com
}

Artikel Info

Kata Kunci: Mitigasi, Bencana, Teks

Prosedur,

Pembelajaran Bahasa
Abstrak

Pendidikan mitigasi bencana dipandang penting untuk diterapkan dalam pembelajaran bahasa Indonesia melalui pembelajaran teks. Oleh sebab itu, tujuan penelitian ini yaitu untuk mendeskripsikan bentuk kearifan lokal Suku Sasak yang dapat diintegrasikan sebagai pendidikan mitigasi bencana berbasis kearifan lokal Suku Sasak dan untuk menjelaskan bentuk pengintegrasian pendidikan mitigasi bencana dalam pembelajaran teks prosedur pada pembelajaran bahasa Indonesia. Metode yang digunakan dalam penelitian ini yakni kualitatif deskriptif. Adapun teknik pengumpulan data dilakukan dengan cara wawancara, observasi dan telaah pustaka mengenai budaya dan tradisi orang Sasak. Adapun hasil yang diperoleh dalam penelitian ini yaitu terdapat 10 bentuk kearifan lokal suku Sasak yang dapat dijadikan mitigasi bencana dan memiliki unsur pembentukan teks prosedur. Selanjutnya, bentuk pengintegrasian pendidikan mitigasi bencana berbasis kearifan Lokal Suku Sasak dalam pembelajaran bahasa Indonesia kelas XI SMA dengan cara menjadikannya sebagai bahan literasi. Adapun kriteria pendukung kearifan lokal Suku Sasak dapat dijadikan literasi mitigasi bencana yaitu 1) Kearifan lokal suku Sasak diwariskan secara turun temurun dari lisan ke lisan. 2) Pengembangan literasi baca tulis mitigasi bencana berbasis kearifan lokal Suku Sasak memiliki prinsip responsif dan adaftif. 3) Struktur kearifan lokal Suku Sasak berbasis mitigasi bencana memiliki relevansi dengan struktur dalam teks prosedur, dan 4) Kearifan lokal suku Sasak mengandung nilai-nilai pendidikan mitigasi bencana. Masyarakat Suku Sasak di Lombok memiliki kearifan lokal yang mampu menciptakan harmonisasi antara satu makhluk dengan makhluk yang lain.

\section{A. PENDAhuluan}

Indonesia memiliki potensi yang cukup besar terdampak berbagai bencana alam seperti gempa bumi, gunung meletus, banjir, tanah longsor, angin puting beliung, kekeringan dan tsunami, (Muslim, 2020).

Munculnya berbagai teknologi, infrastruktur, dan pola mitigasi bencana 
yang lebih modern belum mampu sepenuhnya memberikan jawaban tentang bagaimana mengurangi risiko yang ditimbulkan oleh bencana. Justru semakin banyak kebakaran hutan, banjir, gempa bumi, gunung meletus yang menelan korban jiwa dan harta benda. Hal ini dapat dibuktikan ketika bencana gempa bumi Lombok pada bulan Juli dan Agustus 2018. Berdasarkan data yang dirilis oleh kompas.com pada 01/10/2018 bahwa koraban meninggal dunia yakni 564 orang dan 1.854 korban luka-luka serta kerugian negara ditaksirkan sekitar 8,8 Triliun rupiah.

Keunikan gempa bumi di Lombok yakni bangunan-banguan rumah warga yang dibuat berdasarkan arsitektur warisan nenek moyang sama sekali tidak mengalami kerusakan, masih tetap berdiri kokoh walaupun diguncang gempa berkekuatan 7 SR. Justru bangunan rumah dan kantorkantor pemerintah yang dibangun dengan arsitektur modern mengalami rusak parah.

Hal ini dapat diduga nenek moyang terdahulu memiliki system mitigasi bencana yang kuat yang tertuang dalam kearifan lokal. Masyarakat Suku Sasak di Lombok memiliki kearifan lokal yang mampu menciptakan harmonisasi antara satu makhluk dengan makhluk yang lain. Oleh sebab itu, kearifan lokal dapat dijadikan sebagai pendidikan mitigasi bencana yang dapat dikemas dalam bentuk bahan literasi.

Handayani dalam kompasiana.com (2014), kesiagaan terhadap bencana dengan tingkat literasi yang tinggi umumnya memiliki ketangguhan dan kesiagaan terhadap bencana. Ketersediaan bahan literasi tentang bencana masih sulit ditemukan di sekolah-sekolah. Sebagai contoh kecil dalam observasi awal yang dilakukan oleh peneliti pada 1 Agustus 2019 di Perpustakaan MAN 1 Lombok Timur tidak ditemukan bahan bacaan pendidikan mitigasi bencana alam. Selanjutnya dalam pembelajaran bahasa Indonesia, khusunya dalam pembelajaran teks prosedur belum banyak teks yang menjajikan prosedur penyelamatan diri ketika bencana baik yang berbasis lokal maupun nasional.

Penelitian tentang mitigasi bencana berbasis kearifan lokal telah banyak dilakukan oleh peneliti-peneliti sebelumnya, seperti yang dilakukan oleh Suparmini dkk. (2015); Thene, (2018). Penelitian Suparmini dkk. (2015) mengkaji bentuk-bentuk kearifan lokal masyarakat Baduy dalam mitigasi bencana. Penelitian Thane, (2018) memfokuskan penelitiannya pada mitigasi bencana gempa bumi berbasis kearifan lokal masyarakat Rote Ndao Nusa Tenggara Timur. Selanjutnya, penelitian Maryani dan Yani, (2016); Suarmika dan Utama, (2017); Erianjoni, (2018); AL-Nashar, (2018). Penelitian Maryani dan Yani mengkaji tentang Kearifan Lokal Masyarakat Sunda dalam Memitigasi Bencana dan Aplikasinya Sebagai Sumber Pembelajaran IPS Berbasis Nilai. Namun dalam penelitian tidak ada pembahasan mengenai pola pengaplikasiannya dalam pembelajaran IPS. Mitigasi dibagi menjadi dua, sebagaimana yang dikemukakan oleh (Wikantiyoso, 2010) yaitu mitigasi terstruktur dan non terstruktur. Mitigasi terstruktur didefinisikan sebagai upaya untuk memperkuat banguan/ infrastruktur. Sedangkan non struktur menurut (Arsena dkk. 2018) diartikan sebagai penghindaran terhadap area bahaya dan dapat dilakukan denga regulasi, pemberian latihan, pendidikan, dan sistem peringatan. Dengan demikian yang dimaskud dengan mitigasi bencana yaitu suatu usaha untuk mengurangi risiko yang ditimbulkan dari ancaman bahaya bencana baik dilakukan secara terstruktur maupun non struktur. Pendidikan mitigasi bencana menurut (Setiawan, 2018) yaitu usaha menyadarkan masyarakat untuk memahamai potensi bencana yang dihadapi di masa yang akan mendatang agar memiliki karakter siap siaga dalam menghadapi bencana.

Kearifan lokal menurut (Fajarini, 
2014) yaitu pandangan hidup dan ilmu pengetahuan yang dimiliki oleh sekelompok masyarakat lokal yang berupa strategi kehidupan dan aktivitas yang mereka lakukan. Kearifan lokal menurut (Pawitro, 2011) meliputi aspek sosial, budaya, dan sosial ekologi. Selanjutnya dalam bidang arsitektur kearifan lokal mencakup tata bangunan dan tata lingkungan yang bersifat ekologis. Sedangkan kearifan lokal menurut Kreaf dalam (M.Resa dan Hidayati, 2017) yaitu etika dan moralitas yang membantu manusia untuk menjawab pertanyaan moral apa yang harus dilakukan dan bagaimana bertindak dalam pengelolaan lingkungan dan sumber daya alam.

Selanjutnya, Grot dan Wiggel (dalam Seloka, 2015) mengemukakan bahwa teks prosedur merupakan teks yang mendeskripsikan bagaimana menyelesaikan suatau permasalahan sesuai dengan arahan dan petunjuk. Lebih lanjut Grot dan Wiggel menjelaskan bahwa teks prosedur berisi informasi tentang tata cara mengerjakan sesuatu secara sistematis.

Pendidikan mitigasi bencana berbasis kearifan lokal menjadi hal yang sangat penting untuk diintegrasikan menjadi teks dalam pembelajaran bahasa Indonesia. Hal ini didasari karena pembelajaran bahasa Indonesia di daerah-daerah masih menyajikan teks yang kurang kontekstual dengan pengalaman yang dimiliki oleh anakanak didik sehingga terkesan kurang menarik untuk dibaca dan dipelajari. Atas dasar itulah penelitian tentang integrasi pendidikan mitigasi bencana berbasis kearifan lokal Suku Sasak dilakukan sebagai penambahan bahan literasi dalam pembelajaran teks prosedur di sekolah.

\section{B. METODE}

Penelitian ini termasuk ke dalam penelitian kualitatif deskriptif karena mendeskripsikan bentuk-bentuk pendidikan mitigasi bencana berdasarkan kearifan lokal masyarakat Suku
Sasak yang dikemas dalam teks prosedur dan diintegrasikan ke dalam pembelajaran bahasa Indonesia pada siswa kelas XI di SMA. Adapun instrument yang digunakan dalam pengumpulan data yaitu wawancara, observasi dan studi literature mengenai budaya dan tradisi orang Sasak. Instrument wawancara, telaah pustaka, dan observasi digunakan untuk mengumpulkan data terkait dengan kearifan lokal suku Sasak dari lapangan. Teknik analisis data yang digunakan dalam penelitian ini yaitu teknik analisis data kualitatif berupa analisis isi materi dan analisis deskriptif.

\section{HASIL DAN PEMBAHASAN}

\section{Bentuk-Bentuk Mitigasi Bencana} Berbasis Kearifan Lokal Suku Sasak

Berdasarkan hasil penelitian yang dilakukan dengan cara wawancara, observasi dan telaah buku-buku yang membahas tentang budaya masyarakat Suku Sasak maka ditemukan berapa bentuk kearifan lokal yang dapat dijadikan mitigasi bencana. Penentuan data ini didasarkan atas dasar upaya penanggulangan bencana dengan tujuan mengurangi risko yang ditimbulkan. Data-Data terkait mitigasi bencana berbasis kearifan lokal Suku diperoleh dari informant yang berasal dari Lombok Timur, Lombok Barat, dan Kota Mataram. Bentuk mitigasi yang dalam kearifan lokal masyarakat suku Sasak merupakan bentuk ritual dan tindakan yang diyakini dapat mengurangi risiko bencana, baik berupa pembangunan fisik maupun penyadaran dan peningkatan kemampuan dalam menghadapi bencana.

Dasar pengumpulan data dalam penelitian ini mengenai pendidikan mitigasi bencana berbasis kearifan lokal suku Sasak yakni berdasarakan sumber bencana dan jenis-jenis bencana. Bencana dapat 
bersumber dari alam dan manusia itu sendiri. Sedangkan jenis bencana yang dimaksud yakni bencana geologi seperti gempa bumi, gunung meletus, dan tanah longsor. Bencana iklim seperti banjir, kekeringan, topan, badai. Bencana lingkungan seperti pencemaran lingkungan, penjarahan hutan, alaih fungsi lahan, munculnya wabah penyakit. Dan terakhir bencana sosial yang berupa kehancuran budaya, konfil, dan kerusuhan. Dalam kaitannya dengan jenisjenis bencana tersebut masyarakat Suku Sasak memiliki tata cara yang unik baik dalam bentuk ritual atau aktivitas dalam menanggulangi bencana baik bencana yang ditimbulkan oleh alam maupun bencana yang ditimbulkan oleh manusia itu sendiri.

Data-data yang diperoleh dalam penelitian ini masih banyak diperoleh dari refrensi-refrensi terkait dengan budaya masyarakat Suku Sasak dan hasil wawancara dengan tokoh budaya serta masyarakat Suku Sasak sebagai pelaku dan pemilik budaya. Karena kondisi dalam pengumpulan data masih terhalang oleh pandemi Covid-19 maka data yang dihasilkan dari hasil wawancara masih tergolong sedikit. Karena banyak dari tokoh atau masyarakat belum mau menerima tamu dari luar daerahnya. Upaya yang dilakukan peneliti yakni menghubungi informan melalui handphon. Terdapat 10 bentuk kearifan lokal masyarakat suku Sasak yang dapat dijadikan sebagai pendidikan mitigasi bencana yang dikelasifikasikan ke dalam bentuk mitigasi bencana alam dan bencana yang ditimbulkan oleh manusia itu sendiri. Daerah pengambilan data yakni di Sembalun Lombok Timur, Jrowaru Kabupaten
Lombok Timur, Pringgajurang Kabupaten Lombok Timur, Sakra Kabupaten Lombok Timur, Batu Layar Kabupaten Lombok Barat, dan Kota Mataram.

Masyarakat Suku Sasak dalam memanfaatkan sumber daya alam diikuti dengan pemeliharaan dan pelestarian karena mereka berpandangan alam memiliki sifat yang beraneka ragam namun serasi dan seimbang. Masyarakat Suku Sasak melaksanakan etika lingkungan berdasarkan falsafah hidup secara damai dengan alam. Masyarakat Suku Sasak memiliki hubungan yang sangat dekat dengan alam, mereka meyakini bahwa keramahtamaan terhadap alam akan memberikan manfaar yang besar terhadap kehidupan manusia, (Sudirman, 2014). Wujud kepedulian masyarakat suku Sasak terhadap alam dapat temukan dalam bentuk kearifan lokal yang dimiliki.

Penggolongan data pendidikan mitigasi bencana berbasis kearifan lokal Suku Sasak ini didasarkan atas ciri yang dikemukakan oleh Herani (2018) yaitu: 1) memiliki kemampuan mengendalikan, 2) merupakan benteng untuk bertahan dari pengaruh budaya luar, 3) memiliki kemampuan mengakomodasi budaya luar, 4) Memiliki kemampuan memberi arah pekembangan budaya, 5) memiliki kemampuan mengintegrasi atau menyatukan budaya luar dan budaya asli.

Berikut dijelasakan data kearifan lokal masyarakat Suku Sasak yang dapat dijadikan pendidikan mitigasi bencana dalam pembelajaran teks prosedur pada pembelajaran Bahasa Indonesia di kelas XI SMA. 
Tabel 1. Data Kearifan Lokal Suku Sasak yang Memiliki Nilai Pendidikan Mitigasi

\begin{tabular}{llll}
\hline No & Bentuk Kearifan Lokal & \multicolumn{1}{c}{ Tujuan Mitigasi } & Daerah Penerapan \\
\hline $\mathbf{1}$ & Ritual Turun Bineeq & Mitigasi bencana gagal panen & Sembalun \\
\hline $\mathbf{2}$ & Ngayu-Ayu & Mitigasi pelestarian sumber mata Air & Sembalun \\
\hline $\mathbf{3}$ & Sentulaq & Mitigasi Wabah Penyakit & Jrowaru dan Rembige \\
\hline $\mathbf{4}$ & Maliq & Mitigasi Alam & Lombok \\
\hline $\mathbf{5}$ & Tetulaq Alam & Mitigasi Alam & Sembalun \\
\hline $\mathbf{6}$ & Sentulaq Balak & Mitigasi Penolak Penyakit & Jrowaru, Sakre \\
\hline $\mathbf{7}$ & Nyelametang Aiq & Mitigasi sumber mata air air & Sikur, Montong Gading \\
\hline $\mathbf{8}$ & Bonga Padi & Mitigasi Penanaman Padi & Bayan \\
\hline $\mathbf{9}$ & Perang Timbung & Mitigasi Menolak Marabahaya & Seriwe \\
\hline $\mathbf{1 0}$ & Nyambang dan Pemagar & Mitigasi Penebangan Pohon & Sembalun \\
\hline
\end{tabular}

Pada table 1 di atas merupakan bentuk kearifan lokal suku Sasak yang berpotensi dijadikan sebagai pendidikan mitigasi bencana. Disamping itu bentukbentuk kearifan lokal tersebut memiliki pola pengembangan seperti teks prosedur karena disertai dengan langkah-langkah dalam pelaksanaanya. Berikut penjelasan sebagaian data-data tersebut:

Data (1) Ritual turun bineq merupakan salah satu bentuk ritual menurunkan bibit dari tempat penyimpanan. Ritual ini diyakini dapat memberikan manfaat agar benih yang ditanaman dapat subur dan terhindar dari gagal panen serta dapat meningkatkan produktivitas hasil panen. Ritual turun bineq digolongkan ke dalam kearifan lokal suku Sasak karena merupakan bagian dari budaya yang diwariskan secara turun temurun dari satu generasi ke generasi mulalui tradisi lisan pada masyarakat Suku Sasak. Hal ini merupakan bentuk aktivitas masyarakat Suku Sasak di dalam strategi bercocok tanam. Ritual ini dapat dijadikan sebagai teks prosedur karena memiliki langkahlangkah dan tujuan yang jelas sehingga mudah diaplikasikan. Berikut prosedur dalam pelaksanaan tradisi turun bineq yang dilakukan oleh masyarakat Sembalun . 1) Air diambil terlebih dahulu di sumur jamjam (bukan zam-zam) dan dikumpulkan di berugaq desa. 2) Melakukan penyembelihan ayam putih mulus jantan dan ayam hitam mulus betina. Ayam putih melambangkan kesucian sedangkan ayam hitam melambangkan kesuburan. 3) Bibit padi yang diagunakan sebagai bibit diturunkan melalui panteq (lumbung) dengan menggunakan tali secara belahan-lahan. 4) Bibit padi yang sudah diturunkan diletakan di bahwa lumbung sementara air yang sudah diambil diletakan pada wadah yang terbuat dari perak atau emas. 5) Air yang ditaruh di dalam wadah dimasukan kunyit, kapuk, beras, daun bikan, dan daun jeringo, proses ini disebut dengan bubus padi, 6) Bubus padi diselipkan pada bibit padi yang akan disemakikan sedangkan beras yang direndam dikunyah kemudian disemprotkan dengan menggunakan mulut pada induk padi. 7) Pada acara penyemaian dimulai dengan doa baru dihamparkan. Setelah waktunya ditanam bibit tersebut dicabut untuk ditanam secara bergotong royong.

Data (2) Ngayu-ayu merupakan salah satu tradisi yang masih bertahan di desa Sembalun Kabupaten Lombok Timur yang berupa pesta alam sebagai tanda kesyukuran alam yang telah memberikan manfaat terhadap kelangsungan hidup manusia, terhindar dari bencana. Pada hakikatnya budaya ini merupakan wujud hubungan manusia dengan Tuhan dan alam semesta. Istilah Ngayu-ayau menurut Sudirman (2014) berasal dari kata rahayu 
yang berarti memohon keselamatan. Konsep mitigasi bencana dalam budaya ngayu-ayu ini dapat dilihat dari tujuan ritual yang dilaksanakan yakni untuk menjaga kelestarian alam termasuk sumber mata air.

Adapun prosedur pelaksanaan ngayu-ayau secara umum yaitu :1) Upacara ngayu-ayu dilaksanakan setiap tiga tahun sekali oleh masyarakat Sembalun; 2) Upacara ngayu-ayu dipimpin oleh seorang pemangku, kyai, krama desa; 3) Pada hari pertama dilakukan pengumpulan air dari tujuh sumber mata air yang mengalir yang dimanfaatkan oleh masyarakat; 4) Setelah itu, air yang sudah diambil akan ditaruh di rumah ketua adat selama satu malam kemudian pada keesokan harinya dikumpulkan di makam adat; 5) Pada hari kedua dilanjutkan dengan penyembelihan kerbau yang dilakukan oleh ketua adat yang selanjutnya kerbau tersebut ditanam sebagai pasak bumi (pengaman) desa Sembalun dari bala bencana sementara dagingnya dimasak untuk disantap dengan cara begibung (secara bersama-sama). 6) Setelah itu dilakukan ritual Mafakin yang dilakukan dengan ketua adat membaca doa selama penurunan bibit padi merah dari lembang sampai proses penyamaian; 7) selanjutnya dilakukan upacara perang topat.

Data (3) Sentulaq merupakan salah satu bentuk mitigasi bencana penolak penyakit yang dilakukan oleh masyarakat Jrowaru Kabupaten Lombok Timur. Sedangkan masyarakat Rembige Kota Mataram mengistilahkan dengan istilah "Betetulak" dengan tujuan yang sama yakni sebagai ritual penolak bala atau musibah dari berbagai macam penyakit. Perbedaanya hanya masalah dialek saja namun tujuannya sama. Pendidikan mitigasi bencana melalui tradisi sentulaq atau betetulak ini yakni dalam bentuk ritual namun dalam ritual tersebut terdapat makna dan tanda yang mengarah pada usaha mengurangi risiko yang ditimbulkan dari bencana. Untuk mengetahui bagaimana prosesi dalam pelaksanaan budaya betetulak, berikut disajikan prosedur atau langkah-langkah pelaksanaanya.

Prosedur dalam budaya sentulaq yakni 1) Ritual ini dipimpin oleh tokoh adat setempat yang kemudian mengumpulkan masyarakat; 2) Menghidangkan bahan makanan (Sesajen) yang berbeda selama lima hari berturut-turut; 3) Pada hari pertama dan kedua wajib menghidangkan bubur putih dan bubur merah; 4) Selanjutnya pada hari ketiga mengidangkan serabi: 5) Pada hari keempat menghidangkan ketupat 6) Sedangkan pada hari kelima menhidangkan nasi kemudian dilanjutkan dengan memandikan benda-benda pusaka (Keri dan tombak) dan 7) Ritual ini kemudian ditutup dengan mengarak benda pusaka dan azimat yang diiringi dengan membaca doa. Namun jika dalam kasus penanggulangan hama seperti hama wareng atau ulat maka jajanan lokal yang disuguhkan dalam upacara ini adalah jajanan ulet-ulet (jajan terbuat dari tepung tapi dibentuk seperti ulat). Sementara itu jika bertujuan untuk penanggulangan hama tikus maka jajanan lokal yang disajikan yakni jajanan mas pondoh.

Data (4) Maliq adalah adalah tempat yang harus dihormati karena memiliki kekuatan gaib yang dapat memberikan akibat buruk bila dilanggar atau tidak dihormati. Hal ini dimaksudkan agar sesato (hewan), kekayon (Tumbuhan), kumilit kumalat, (penghuni alam selain manusia) tidak terganggu dengan kehadiran dan perlakuan manusia, Sudirman (2014). Maliq dapat diartikan sebagao suatu pantangan, tidak elok (bukan hanya tidak boleh). Orang Sasak pantang berbuat hal-hal yang bertentangan dalam bukan hanya aturan yang tegas dalam agama tetapi juga bertentangan dengan bukan hanya aturan yang tegas dalam agama tetapi juga yang bertentangan dengan adab, tata krma atau etikat dalam agama, (Wahyudin, 2017). Dari maliq munculah tradisi yang berkaitan dengan awiq-awiq penebangan kayu dan 
pantangannya. Tradisi dengan pembukaan tanah baru dan tradisi-tradisi yang berkaitan dengan pertanian. Tradisi yang berkaitan dengan pengelolaan sumber mata air, penggalian sumur, pelestarian daerah aliran sungai. Tradisi yang berkaitan dengan binatang sebagai penghuni dan penjaga kelangsungan ekosistem hutan, sawah, dan kebun.

Berikut prosedur yang dilakukan dalam menebang pohon khusus untuk komunitas masyarakat adat di Bayan Lombok Utara. 1) Sebelum menebang pohon harus melakukan permintaan izin kepada makhluk halus yang dipercayai sebagai peninggu pohon, 2) Hasil limbah pohon yang dihasilkan harus dibuang pada tempat atau lokasi yang dimiliki oleh masyarakat adat. Pelanggaran tata cara menebang pohon menurut kepercayaan sebagaian masyarakat dapat menimbulkan maliq. Pendidikan Mitigasi dalam tradisi maliq yakni dapat mencegah penggundulan hutan, penebangan pohon secara sembarangan. Masyarakat Suku Sasak yang ada di Desa Sade Kabupaten Lombok Tengah memiliki Kemaliq yakni larangan memasuki hutan secara sembarangan yang apabila dilanggar akan mendapatkan musibah pada atau gangguan di kemudian hari, (lihat Mansur, 2018). Kearifan lokal masyarakat Suku Sasak terhadap pelestarian hutan sangat kuat dan inilah yang terkadang saat sekarang ini sudah mulai pudar digerus oleh pengaruh zaman dan teknologi.

Data (5) Tetulaq Alam merupakan bentuk perwujudan penghormatan manusia kepada alam, konon katanya, dengan mengadakan ritual ini masyarakat pada umumnya akan dijaga oleh alam dengan kehendak yang maha kuasa. Alam dianggap sebagai ibu dari seluruh manusia, karena pada dasarnya manusia dapat hidup dibantu dengan alam, seperti keberadaan air, pohon, oksigen dll. Selama ini alam tidak pernah meminta balasan dari apa telah diberikan, bahkan kita cenderung merusak dan menyia- nyiakan alam tersebut.

Tetulaq alam memiliki makna filosofis yang dalam bagi masyarakat sembalun bubung dalam menyikapi setiap musibah yang datang sebelum dan sesudahnya. Tetulaq dalam bahasa sasak berarti kembali dan alam artinya kepada alam itu sendiri seperti hutan, sungai, gunung dan lain-lain. Oleh sebab itu, tetulaq alam dipandang sebagi bentuk perwujudan rasa hormat kepada alam yang telah dihadirkan oleh Allah SWT. Sehingga masyarakat diarahkan kepada kembali kepada alam atau tetulaq alam, disisi lain, tetulaq alam bermakna juga sebagai bentuk menolak bencana atau tetulaq balaq. Budaya tetulaq alam hadir dengan sifatnya yang situasional, bukan ceremonial seperti Ngayu-Ayu. Budaya ini bersifat fleksibel dan diperuntukan kepada semua bencana yang telah terjadi. Seperti gempa, longsor, kekeringan dll. Budaya tetulaq alam ini dipimpin oleh seorang tokoh budayawan yang dipercaya masyarakat. Berikut caracara tetulaq alam di Desa Sembalun Bumbung: 1) Siapkan penginang atau wadah; 2) Isi penginang tersebut dengan 9 leqoq (daun sirih), 9 buaq (buah pinang), atau sirih kojong (Sirih yang dibuat mengkrucut); 3) Siapkan Kemenyan di dalamnya; 4) Bakar kemenyan; 5) Upacara dimulai dengan dipimpin oleh pemimpin adat dengan membacakan mantra-mantra yang berisi doa-doa dalam bahasa sasak terdahulu; 5) Setelah itu, dzikir dan doa. Meminta segala bentuk bantuan kepada Allah SWT dan 6) Makan Bersama.

Nilai pendidikan mitigasi bencana dalam tradisi Tetulaq alam yaitu menumbuhkan kesadaran kepada masyarakat Suku Sasak kepada pelestarian alam. Dengan kesadaran menjaga alam yang dimiliki oleh masyarakat maka dapat menghindari bencana yang ditimbulkan oleh alam seperti longsor, pencemaran air, pengundulan hutan dan bencana alam lainnya. Kesadaran kolektif terhadap 
pelestarian alam menggambarkan salah satu cerminan budaya orang Sasak sebagai masyarakat yang peduli terhadap lingkungan.

\section{Bentuk Pengintegrasian Pendidikan Mitigasi Bencana dalam Pembelajaran Bahasa pada kelas XI SMA}

Dalam konteks pendidikan mitigasi bencana sudah saatnya para peserta didik diperkenalkan tentang tata cara menghindari bahaya bencana dengan cara yang berkembang di daerahnya masing-masing atau berdasarkan kearifan lokal yang berkembang di daerahnya masing-masing. Kearifan lokal yang berisi pendidikan mitigasi bencana dapat dikembangkan sebagai bahan literasi yang kemudian diintegrasikan dalam pembelajaran di kelas.

Desyandri (2018) menjelaskan bahwa pembelajaran di sekolah dasar dapat dilakukan dengan mengabungkan dan menyisipkan nilai-nilai kearifan lokal sebagai literasi budaya. Selanjutnya UU No.31 Tahun 2009 tentang Perlindungan dan Pengelolaan Lingkungan Hidup menyatakan bahwa kearifan lokal adalah nilai-nilai leluhur yang berlaku dalam tata kehidupan masyarakat antara lain melindungi dan mengelola lingkungan hidup secara lestari. Dengan demikian, kearifan lokal Suku Sasak dipandang sebagai suatu kekayaan lokal yang dapat menjadi pendidikan mitigasi dalam melindungi dan mengelola lingkingan hidup agar tidak menimbulkan bencana alam.

Data kearifan lokal suku Sasak yang didapatkan dalam penelitian ini memiliki potensi untuk dijadikan sebagai literasi mitigasi bencana yang dikemas dalam bentuk teks prosedur. Adapun kriteria yang mendukung bahwa kearifan lokal Suku Sasak dapat dijadikan sebagai literasi mitigasi bencana yang dapat dikemas dalam bentuk teks prosedur yaitu sebagai berikut.

1) Kearifan lokal suku Sasak yang diwariskan secara turun temurun dari lisan ke lisan dapat dijadikan sebagai literasi baca tulis. Kemendigbud (2017) menyebutkan bahwa literasi baca tulis disebut sebagai moyang segala jenis literasi karena memiliki sejarah amat panjang, bahkan disebut sebagai awal literasi. Disamping itu, litrasi baca tulis dipahami sebagai kemampuan berkomunikasi sosial di dalam masyarakat. Kearifan lokal suku Sasak yang diwariksan secara lisan dari satu generasi ke generasi mengalami tantangan berat dimasa sekarang ini jika tidak dialihwanakan ke dalam bentuk tulisan sehingga dapat menjadi bahan bacaan. Nilai-nilai leluhur yang dimiliki oleh Suku Sasak akan punah jika tidak ada yang memiliki kepedulian untuk menjaga dan mendokumentasikan. Atas dasar itulah, bentuk-bentuk kearifan lokal tersebut dipandang tepat untuk dikembangkan ke dalam bentuk literasi baca tulis sehingga dapat diketahui oleh pemilik budaya tersebut.

2) Pengembangan literasi baca tulis mitigasi bencana berbasis kearifan lokal Suku Sasak memiliki prinsip responsif dan adaftif. Salah satu prinsip pengembangan literasi yang dikemukakan oleh Kemdikbud (2017) yakni prinsip responsif kearifan lokal. Nusantara memiliki kekayaan budaya yang beragam perlu didayagunakan dan dimanfaatkan secara optimal dalam perencanaan dan pelaksaan literasi baca tulis di sekolah, keluarga, dan masyarakat sehingga literasi baca tulis mampu merawat, merevitalisasi dan melesteraikan serta meremajakan kearifan lokal Indonesia. Prinsip pengembangan literasi yang dikemukakan oleh Kemendikbud memiliki relevansi 
dalam pengintegrasian mitigasi bencana berbasis kearifan lokal Suku Sasak ke dalam pembelajaran materi teks prosedur dalam pembelajaran Bahasa Indonesia. Tidak hanya dalam implimentasinya dalam bentuk materi namun yang tidak kalah pentingnya yakni kearifan lokal yang merupakan kekayaan bangsa ini dapat terawat dan terjaga. Literasi yang diadaftasi berdasarkan kondisi lingkungan atau budaya peserta didik akan lebih cepat dipahami dan diterima karena memiliki hubungan baik secara pengalaman maupun secara psikologi.

3) Struktur kearifan lokal Suku Sasak berbasis mitigasi bencana memiliki relevansi dengan struktur dalam teks prosedur. Hasil analisis terhadap bentuk-bentuk kearifan lokal Suku Sasak yang mengandung pendidikan mitigasi bencana ditemukan relevansi unsur-unsur dan struktur penyusunan teks prosedur sebagaimana yang dipelajari oleh siswa pada materi pembelajaran Bahasa Indonesia di sekolah. Dalam kearifan lokal Suku Sasak terdapat langkah-langakah secara lengkap dan bencana yang dikemas dalam teks prosedur kemduian dapat dijadikan sebagai materi dalam pembelajaran teks prosedur.

4) Kearifan Lokal Suku Sasak mengandung nilai-nilai pendidikan Mitigasi Bencana. Mitigasi merupakan upaya yang ditujukan untuk mengurangi dampak dari bencana alam, bencana ulah manusia, atau keduanya dalam satau negara atau masyarakat sistematis tentang tata cara melakukan sesuatu penangan dalam penanggulangan bencana. Hal ini sesuai dengan pengertian teks prosedur yang dikemukakan oleh Kosasih (2014) yaitu teks prosedur adalah teks yang menjelaskan langkah-langkah secara lengkap dan sistematis tentang cara melakukan sesuatu atau trik dan kiat melakukan sesuatu. Selanjutnya setelah melakukan analisis terhadap data kearifan lokal yang sudah disajikan pada bagian pembasan ini maka dapat ditemukan struktur teks prosedur seperti pernyataan umum yang berisi gambaran umum dari isi petunjuk, tahap-tahap kegiatan, dan penegasan ulang. Struktur kearifan lokal suku Sasak jika digolongkan ke dalam macam-macam teks prosedur maka dapat digolongkan ke dalam teks prosedur yang menginformasikan aktivitas tertentu dan peraturannya dan teks prosedur yang berhubungan dengan sifat atau kebiasaan manusia dalam menangani suatu masalah atau bencana. Dengan demikian dapat diambil kesimpulan bahwa kearifan lokal suku Sasak dapat dijadikan sebagai bahan literasi pendidikan mitigasi (Permendagri No 33 tahu 2006). Dalam kaitannya dengan penerapannya di sekolah, maka mitigasi bencana berbasis kearifan lokal dapat dijadikan sebagai bahan literasi kemdian dirangkaikan dalam bentuk teks prosedur agar mudah dipahami oleh peserta didik. Adapun langkah-langkah penerapannya dalam pembelajaran di sekolah khusunya pada pembelajaran bahasa Indonesia yakni sebagai berikut. 
Bagan 1: Pola Pengintegrasian Pendidikan Mitigasi Bencana Berbasis Kearifan Lokal Suku Sasak pada Pembelajaran Bahasa

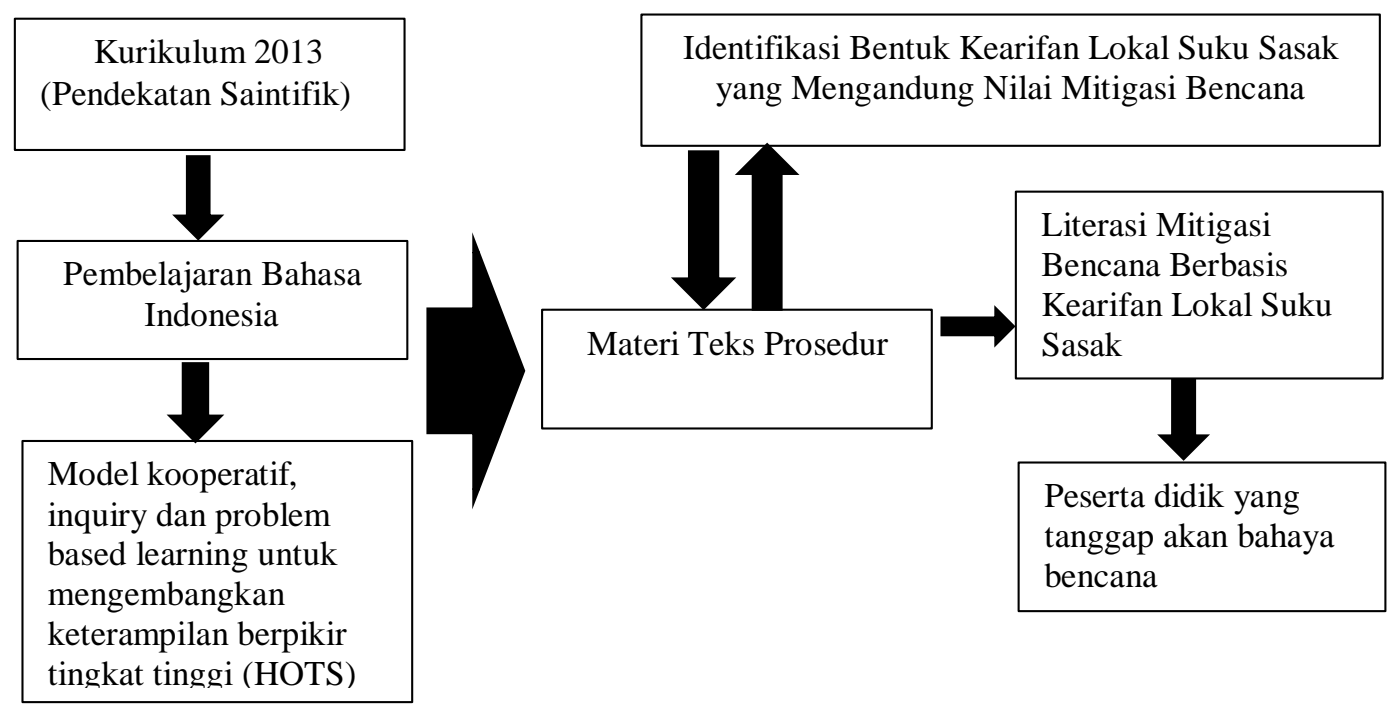

\section{PENUTUP}

Berdasarkan hasil pembahasan pada artikel ini maka dapat disimpulkan bahwa kearifan lokal suku Sasak memiliki potensi untuk dijadikan sebagai pendidikan mitigasi bencana. Bentuk pendidikan mitigasi bencana yang berkembang pada masyarakat Suku Sasak yakni berupa ritual adat dan budaya yang diyakini oleh pemiliknya mampu menolak bencana. Kemudian masyarakat suku Sasak meyakini bahwa bencana yang ditimbulkan di muka bumi adalah bagian dari kehendak Allah yang disebabkan karena tingkah laku manusia yang tidak bisa menjaga alam dan tidak menghargai sesama makhluk ciptaan Tuhan. Oleh sebab itu, dalam bentuk ritual mitigasi bencana berbasis kearifan lokal suku Sasak memiliki kaitan erat dengan nilai-nilai keislaman. Budaya dan Agama hidup berdampingan saling melengkapi di tengahtengah kehidupan orang Sasak. Sementara itu, bentuk pengintegrasian pendidikan mitigasi bencana berbasis kearifan lokal dalam pembelajaran bahasa yakni dengan cara dijadikannya kearifan lokal suku Sasak sebagai bahan literasi yang dapat dijadikan sebagai materi pembelajaran Bahasa Indonesia pada kelas XI di SMA.

\section{E. UCAPAN TERIMA KASIH}

Penelitian ini dapat terlaksana berkat dukungan dari Menristek-BRIN, peneliti tidak lupa mengucapkan terima kasih yang sebesar-besarnya atas dana yang diberikan dalam mendukung penelitian dosen pemula (PDP) tahun pelaksanaan 2020. Semoga penelitian ini dapat bermanfaat bagi pengembangan ilmu pengetahuan sebagaimana yang dicicta-citakan oleh Menristek-BRIN.

\section{DAFTAR PUSTAKA}

AL-Nashr, M. S. (2018). Integrasi pendidikan siaga bencana dalam kurikulum madrasah ibtidaiyah. Magistra : Media Pengembangan Ilmu Pendidikan Dasar Dan Keislaman. https://doi.org/10.31942/mgs.v6i2.177 9

Arsena dkk. 2018. Perencanaan Perasarana Perkotaan. Yogyakarta:CV Budi Utama. 
Bahri dan Sudirman. 2014. Studi Sejarah dan Budaya Lombok. Pringgabaya: Pusat Studi dan Kajian Budaya Prov NTB (Puskanda).

Erianjoni, E. (2018). Pengembangan Materi Ajar Sosiologi Tentang Mitigasi Bencana Berbasis Kearifan Lokal Di Kota Padang. SOCIUS. https://doi.org/10.24036/scs.v4i2.24

Fajarini, U. (2014). Peranan Kearifan Lokal Dalam Pendidikan Karakter. Sosio didaktika: Social Science Education Journal. https://doi.org/10.15408/sd.v1i2.1225

Fathurraman, Lalu Agus. 2016. Membaca Arsitektur Sasak. Mataram: Genius. 2017. Kosmologi Sasak: Risalah Inen Paer. Mataram: Genius.

Https://regional.kompas.com/read/2018/09/ 23/11321551/melihat-kembali-gempalombok-2018-dan-sejarahkegempaannya?page $=$ all diakses pada tanggal 20 Juli 2019.

Hernani. 2028. Pengembangan Bahan Ajar Teks Prosedur Berbasis Kearifan Lokal bagi Sisiswa kelas XI SMA. Tesis Magister Universitas Muhammadiyah Purwokerto.

Jamaluddin. 2018. Sejarah Islam Lombok. Yogyakarta:Ruas Media.

Kemendikbud. 2017. Materi Pendukung Literasi Baca Tulis. Jakarta: Kemendikbud.

Kurniawan, Heru. 2015. Pembelajaran Kreatif Bahasa Indonesia Kurikulum 2013. Jakarta:Prenadamedia.

Kosasih. 2014. Jenis-Jenis Teks. Bandung. Yrama Widya.

Maryani, E., \& Yani, A. (2016). Kearifan Lokal Masyarakat Sunda Dalam Memitigasi Bencana Dan Aplikasinya Sebagai Sumber Pembelajaran Ips Berbasis Nilai. Jurnal Penelitian Pendidikan.

Muslim, B. (2019). Kodifikasi Potensi Materi Teks Pembelajaran Bahasa
Indonesia Kurikulum 2013 Jenjang Sma Untuk Mengembangkan Literasi Mitigasi Bencana. JURNALISTRENDI: JURNAL LINGUISTIK, SASTRA, DAN PENDIDIKAN, 4(2), 324-333.

Priyatni, Endah Tri. 2017. Desain Pembelajaran Bahasa Indonesia Kurikulum 2013. Jakarta: Bumi Aksara.

Pawitro, U. (2011). Prinsip-Prinsip "Kearifan Lokal" dan Kemandirian "Berhuni" pada Arsitektur Rumah Tinggal "Suku Sasak" Di Lombok Barat. In Simposium Nasional RAPI X FT UMS.

Reza, Mohammad, and Agustina Nurul Hidayati. "Kearifan Lokal Suku Sasak Dalam Pengelolaan Sumber Daya Air Desa Lenek Daya, Kecamatan Aikmel Kabupaten Lombok Timur." Jurnal Spectra 15, no. 30 (2017): 1-14.

Samsyiah, Nur. 2019. Pengembangan Literasi Baca Audio Visual Berbasis Kearifan Lokal di Kabupaten Madiun. Prosiding Seminar Nasional.

Sari, J. P. Yunisrul; Desyandri.(2018). Peningkatan Pembelajaran Tematik dengan Pendekatan Scaintifik di Kelas I SDN 15 Ulu Gadut, Kota Padang. Ejournal Pembelajaran Inovasi: Jurnal Ilmiah Pendidikan Dasar, 6 (1), 11-24.

Seloka .2015. Pengembangan Bahan Ajar Interaktif Kompetensi Memproduksi Teks Prosedur Kompleksyang Bermuatan Kesantunan Bagi Peserta Didik Kelas X Sma/Ma. - Jurnal Pendidikan Bahasa Dan Sastra Indonesia.

Setiawan, Agnas.2018.Membuka Wawasan dengan Geografi.Yogyakarta:CV Budi Utama.

Sorraya, A. (2014). Pengembangan Bahan Ajar Teks Prosedur Kompleks Dalam Pembelajaran Bahasa Indonesia Untuk Kelas X SMK. NOSI.

Suarmika, P. E., \& Utama, E. G. (2017). Pendidikan Mitigasi Bencana Di Sekolah Dasar (Sebuah Kajian Analisis 
Etnopedagogi). JPDI (Jurnal Pendidikan Dasar Indonesia). https://doi.org/10.26737/jpdi.v2i2.327

Suparmini, S., Setyawati, S., \& Sumunar, D. (2015). Mitigasi Bencana Berbasis Kearifan Lokal Masyarakat Baduy. Humaniora.

Suryaningsih, E., \& Fatmawati, L. (2017). Pengembangan buku cerita bergambar tentang mitigasi bencana erupsi gunung api untuk siswa sd. Profesi pendidikan dasar. https://doi.org/https://doi.org/10.23917 /ppd.v1i2.5310

Thene, J. (2018). Mitigasi Bencana Gempa Bumi Berbasis Kearifan Lokal Masyarakat Rote Kabupaten Rote Ndao Provinsi Nusa Tenggara Timur. Jurnal Teori Dan Praksis Pembelajaran IPS. https://doi.org/10.17977/um022v1i220 $16 \mathrm{p} 102$

Wikantiyoso, R., Utara, S., \& Barat, S. (2010). Mitigasi Bencana Di Perkotaan; Adaptasi Atau Antisipasi Perencanaan Dan Perancangan Kota? ( Potensi Kearifan Lokal Dalam Perencanaan Dan Perancangan Kota Untuk Upaya Mitigasi Bencana ). LOCAL WISDOM. 